AperTO - Archivio Istituzionale Open Access dell'Università di Torino

WHEN WORK ENRICHES FAMILY-LIFE: THE MEDIATIONAL ROLE OF PROFESSIONAL DEVELOPMENT OPPORTUNITIES

This is the author's manuscript

Original Citation:

Availability:

This version is available http://hdl.handle.net/2318/123305

since 2015-12-23T15:51:05Z

Published version:

DOI: $10.1108 / 13665621311299780$

Terms of use:

Open Access

Anyone can freely access the full text of works made available as "Open Access". Works made available under a Creative Commons license can be used according to the terms and conditions of said license. Use of all other works requires consent of the right holder (author or publisher) if not exempted from copyright protection by the applicable law. 


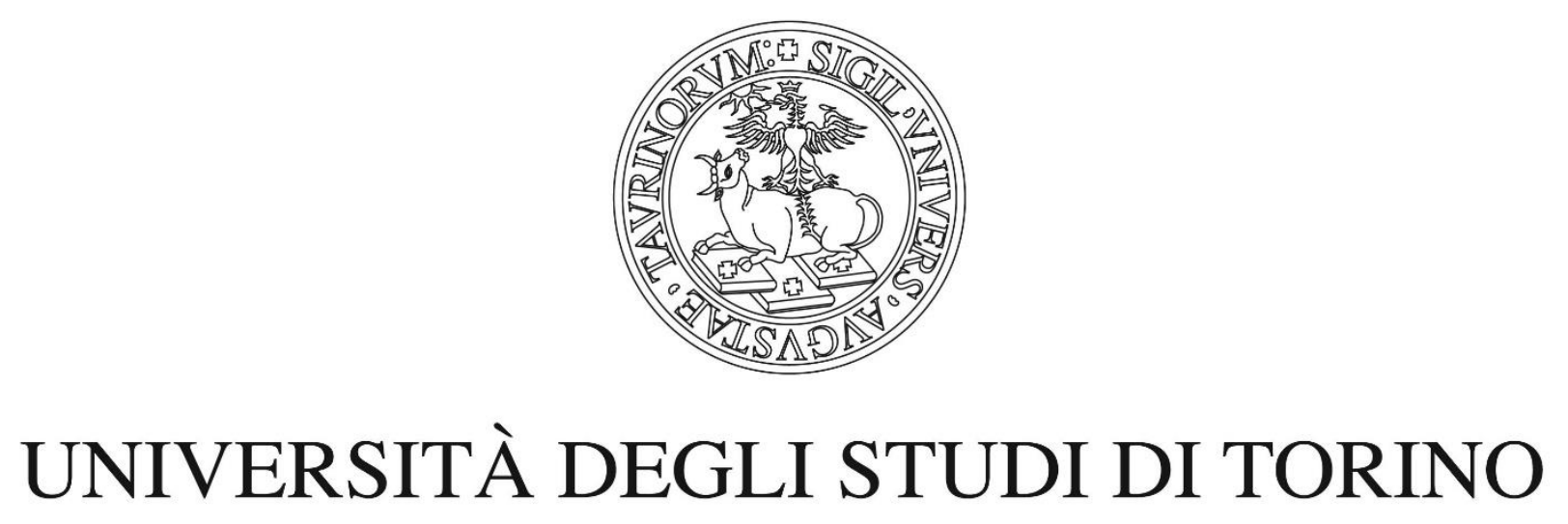

This is an author version of the contribution published on:

Questa è la versione dell'autore dell'opera:

Molino, M., Ghislieri, C., \& Cortese, C. G. (2013). When work enriches family-life: the mediational role of professional development opportunities. Journal of Workplace Learning, 25(2), 98-113. DOI: 10.1108/13665621311299780

The definitive version is available at:

La versione definitiva è disponibile alla URL:

http://dx.doi.org/10.1108/13665621311299780 
WHEN WORK ENRICHES FAMILY LIFE: THE MEDIATIONAL ROLE OF PROFESSIONAL DEVELOPMENT OPPORTUNITIES

Monica Molino*, Chiara Ghislieri*, \& Claudio G. Cortese*

*Psychology Department, University of Turin, Via Verdi 10, 10124, Turin, Italy.

Corresponding author: Monica Molino, Psychology Department, Via Verdi 10, 10124 Turin, Italy.

Phone number: +39 011 6702050. e-mail address: monica.molino@unito.it 


\section{WHEN WORK ENRICHES FAMILY LIFE: THE MEDIATIONAL ROLE OF PROFESSIONAL DEVELOPMENT OPPORTUNITIES}

\section{Structured Abstract:}

Purpose. Several studies have pointed out the importance of work-family enrichment (WFE) for individuals' well-being and organizations; for this reason, it seems important to understand how organizations may promote it. This study attempts to understand the role of organizational resources and, particularly, of opportunities for professional development (OPD), in promoting WFE. Specifically, it tests the mediation role of OPD between job resources (supervisor and colleague support, job security) and WFE.

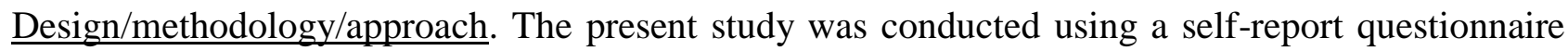
administered to 353 employees and self-employed workers from different occupational sectors.

Findings. Filling a gap in the literature, the results showed that two job resources (supervisor support and job security) increase OPD which, in turn, mediates the relationship between the two job resources and WFE. Colleague support showed only a direct positive effect on WFE.

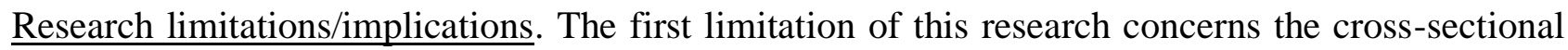
design of the study, due to which no causal conclusions can be drawn. Moreover, future research might integrate some job demands and additional job resources into the model. Finally, a deeper understanding of the construct of OPD emerged as necessary, as well as more accurate instruments to measure it.

Practical implications. Based on our findings, organizations are encouraged to improve opportunities for job training and professional development, with important benefits for individuals, in terms of quality of work and life, and for organizations, in terms of better job attitudes and performance. Moreover, as regards job security, more protection should be given to workers in order to enhance the quality of workplace learning and extra-work life. 
Originality/value. This study highlighted the importance of integrating OPD into work-family studies, demonstrating their role in enhancing the quality of life in the family domain. Furthermore, this study is one of the first to focus on job security as a significant resource in promoting professional development.

Keywords: Work-family enrichment, job demands-resources model, professional development, job security

Article Classification: Research paper

\section{Introduction}

The work-family interface, defined as the interconnected relationship between work and family domains (Voydanoff, 2005), is a well-established research topic nowadays (Yanchus et al., 2010). The increase in research on it over the past decades is linked to shifting demographics, including more working women, dual-career couples, single-parent families (Major and Germano, 2006) and, more recently, to the information era (MacDermid, 2005). Given these changes, more employees report difficulties in juggling responsibilities in the two most important domains of adult life, namely, work and family.

The work-family interface can be looked at according to two different perspectives, the first one, which was given much importance in early studies, regarding work-family conflict (WFC) and the second one, more developed in recent years, regarding work-family enrichment (WFE). Both WFC and WFE are characterized by a process in which one's functioning and behaviour in one domain is influenced by quantitative and qualitative demands and resources from the other domain (Demerouti, Bakker and Voydanoff, 2010; Demerouti, Geurts and Kompier, 2004). 
On the one hand, WFC is defined as an incompatibility between the work and family roles (Greenhaus and Beutell, 1985). The conflict model is based on the idea that a person has a limited amount of time and energy to engage in different roles (scarcity hypothesis; Goode, 1960) and strain is inevitable (given the over-demanding nature of engaging in multiple roles). In the 1990s, the use of this construct was criticized (Kirchmeyer, 1993): the WFC perspective was considered damaging to the growth of women's participation in work and contributed to the hypothesis of women's lower productivity, due to their multiple roles.

On the other hand, WFE is defined as the extent to which experiences in one role enhance performance in the other one (Greenhaus and Powell, 2006). The enhancement hypothesis (Marks, 1977; Sieber, 1974; Thoits, 1983), indeed, suggests that occupying multiple roles can be positive. Crouter (1984) identified positive spillover between family and work as the "neglected face" of studies in this domain.

In recent years, several studies have pointed out the importance of WFE for individuals and organizations (Carlson et al., 2011). The hypothesis that individuals' work roles may be a source of WFE (Greenhaus and Powell, 2006), as well as WFC, has become increasingly central (Gareis et al., 2009; Hill et al., 2007). At the same time, scholars showed that WFE is linked to an enhancement of job attitudes, job performance and job satisfaction (Carlson et al., 2011; OdleDusseau, Britt and Greene-Shortridge, 2012; Shockley and Singla, 2011).

Considering these findings, and taking an organizational point of view, this study focuses on WFE in the work-to-family direction and on its determinants derived from the work domain (see, amongst others, Lapierre and Allen, 2006), assuming that organizations can have an influence especially on this direction (Carlson et al., 2006; Frone, Russel and Cooper, 1992; Ghislieri et al., 2011). Moreover, the increase of WFE can also positively impact job satisfaction: a recent metaanalysis (Shockley and Singla, 2011) showed that positive affective reactions to WFE occur mostly in the originating, rather than receiving, domain (supporting the source attribution perspective). 
For this reason, it is important for organizations to understand how they can increase WFE (Bakker et al., 2011). Therefore, using the job demands-resources (JD-R) model as a framework (Bakker and Demerouti, 2007), this study aims to understand the effects of job resources on WFE. Specifically, besides the traditional job resources that have been already considered in literature (e.g. supervisor support, colleague support; Siu et al., 2010), the study takes into account also the role of opportunities for professional development (OPD), a still understudied construct that can play an important role in the enrichment process (Bakker et al., 2011). Indeed, while the benefits of being engaged in both work and family have been recognized for over 30 years (Sieber, 1974), little empirical research in this field has considered the role of OPD (Bakker and Geurts, 2004) and this kind of research has never been carried out in Italy before.

\section{Theoretical Context}

\section{Work-family enrichment}

While other theoretical models have been used to understand the work-family interface (compensation, instrumentality, integration/segmentation, role identity and balance; Edwards and Rothbard, 2000; Ghislieri et al., 2011; O’Driscoll, Brough and Kalliath, 2006; Poelmans, O'Driscoll and Beham, 2005; Rothbard and Dumas, 2006), the conflict perspective dominated two decades of work-family studies (1980s and 1990s). In the 2000s the trend has changed: research paired the study of WFE with the study of WFC.

Besides WFE (Greenhaus and Powell, 2006), other constructs were proposed to describe the benefits of being committed in both work and family (Odle-Dusseau, Britt and Greene-Shortridge, 2012), including work-family positive spillover (Edwards and Rothbard, 2000; Hanson, Hammer and Colton, 2006), work-family facilitation (Grzywacz, 2002) and work-family enhancement (Tiedje et al., 1990). The distinction among these constructs is often fuzzy (Ghislieri et al., 2011; Hammer and Hanson, 2006). We chose the construct of enrichment since its definition is inclusive of all concepts listed above (see Greenhaus and Powell, 2006 for a comprehensive explanation). 
Enrichment is a process by which one role (the work or family one) enhances the other one. More specifically, it occurs when resources generated in one role improve the quality of life in another role (Greenhaus and Powell, 2006). Greenhaus and Powell's definition of the concept of resources (2006) is an extensive one which includes personal, social capital and material assets. The authors also suggest that there are two possible processes: 1) an instrumental path to enrichment - when a resource generated in one role is transferred directly from one role to another (enhancing performance in the receiving role); 2) an affective path to enrichment - when a resource generated in one role promotes positive affect in that role, which in turn produces high performance and leads to a positive affect in the second role.

Like WFC, WFE can be bi-directional (from work to family and from family to work). Carlson and colleagues (2006) regarded at enrichment as a multidimensional construct, composed of three dimensions both in the work-to-family direction (development, affect and capital), and in the family-to-work direction (development, affect and efficiency).

Enrichment seems to be influenced by some dispositional aspects, such as extraversion (Wayne, Musisca and Fleeson, 2004) and positive affectivity (Michel and Clark, 2009), and some important antecedents of WFE are identified in organizational and family interest and support (Carlson et al., 2006). Among principal determinants of WFE, the literature has widely considered job resources (Odle-Dusseau et al., 2012; Siu et al., 2010) since they have an important role in enrichment processes, according to the above mentioned definition by Greenhaus and Powell (2006).

The benefits of WFE have been identified in different ways: gaining awareness and/or skills usable in another role; providing a broader frame of reference from which to relate to others; creating a buffer in one role against failure in another domain; enhancing one's self-image; increasing the accessibility of social support; generating energy (Hanson et al., 2006). Some research results confirmed the benefits of engaging in work and family roles to mental, physical and relational wellbeing (Barnett and Hyde, 2001), and the benefits of combining personal and professional lives (Barnett, 1998). 


\section{Opportunities for professional development}

In a modern and changing society, characterized by globalized competition and rapid technological development, workers are continuously required to learn and develop new competencies at work (Coetzer, 2007). Therefore, skill improvement is essential, but little is yet known about how this process of professional development and workplace learning can be supported.

Reorganization of work and new job design require employees to develop knowledge, skills and competencies to cope with workplace and organizational changes (Sugarman, 2001). Moreover, these changes have impacted the health and safety of workers and have increased their exposure to stress (Cox, Griffiths and Rial-Gonzales, 2000; Kompier, 2006; Theorell and Hasselhorn, 2005). Stimulating learning opportunities at work may be an important mechanism by which to develop the adaptive skills of employees necessary to cope with stressful work situations. Indeed, research has indicated that learning opportunities reduce stress (Holman and Wall, 2002), exert positive effects on the quality of work life (Panari et al., 2010) and increase workers' motivation (Morrison et al., 2005).

OPD can be considered an organizational resource that allows employees to cope with continuous changes and growing demands, to achieve their work goals and, consequently, prevent negative outcomes (Salanova, Agut and Peiro, 2005). However, what is meant by professional development has not yet been clearly defined in the literature (Elman, Illfelder-Kaye and Robiner, 2005). A range of different opportunities are provided during the process of work, for example, through activities at work, workers may develop social, emotional, or cognitive competencies, motivation, skills, as well as their self-concept. Elman and colleagues (2005) defined professional development as "the developmental process of acquiring, expanding, refining, and sustaining knowledge, proficiency, skill, and qualifications for competent professional functioning that result in professionalism" (p. 368). They referred both to the internal tasks of clarifying professional objectives and increasing self-awareness and self-confidence on the one hand, and to the social and contextual dimensions of enhancing interpersonal aspects of professional functioning on the other hand. 
One of the dimensions of OPD is workplace learning, which is gaining increasing importance in the education and training of workforces (Jacobs and Park, 2009). Workplace learning enables individuals and organizations to cope with the changing nature of work and the economy: it helps improve efficiency and productivity, and it meets the personal and career development needs of workers (Panari et al., 2010). Workplace learning may be formal, but is actually mainly informal (Rau, 2006). Informal learning is described as unstructured, experimental, non-institutional and integrated into the daily work routines (Holman and Wall, 2002; Morrison et al., 2005).

Hence, OPD are usually associated with workplace learning and skill training designed to improve productivity, but very little research has been conducted on its role within the quality of work and life domains (Bakker et al., 2003). Recently Bakker et al. (2011) studied the buffer effect of OPD on the relationship between job demands and WFC. In this study, we rather hypothesize a direct positive effect of OPD on WFE.

\section{Hypothesis 1 (H1): OPD increase WFE.}

\section{Other job resources}

Work environments that offer many resources foster the willingness to dedicate one's efforts and abilities to completing work tasks (Bakker and Demerouti, 2007). Among other job resources, workplace social support plays a significant role and increases the likelihood of success in attaining work goals. According to one of the most popular and earliest definitions, social support is the belief that the worker is loved, valued, and his well-being is cared about as part of a social network of mutual obligation (Cobb, 1976). Some authors (Tracey, Tannenbaum and Kavanaugh, 1995) have found that employees learn more from informal sources, such as supervisors and colleagues, than from formal learning activities. Learning is in fact a social process, consequently supervisor and colleague support encourages employees' growth and development (Ouweneel et al., 2009). 
Both supervisors and colleagues can provide support that fosters positive work experiences. Supervisor support involves caring about subordinates, valuing their contributions, helping them with work-related issues and facilitating their skill development (Rafferty and Griffin, 2004). Colleague support denotes the degree of assistance and caring received from others, including tangible help, encouragement and information (Ducharme and Martin, 2000).

In today's work environment, characterized by different configurations and new career paths (like protean and boundaryless career; Briscoe, Hall and De Muth, 2006), another important resource is job security. Perceived occupational security is a psychological state concerning workers' expectations of future job continuity (Kraimer et al., 2005). Individual differences in perceived job security may be contingent on organizational practices that affect the current working relationship, on job conditions or on the nature of the psychological contract itself. According to various studies, the objective condition of low employment security has many negative effects on well-being (Connelly and Gallagher, 2004; Falco et al., 2008).

Within this frame of reference, OPD have a fundamental role, because the perception of work experience as an opportunity to grow professionally can influence attitudes towards one's professional future, with implications for the capacity of personal planning (Pombeni and Vattovani, 2005) and the ability to cope with low job security (Panari et al., 2010). At the same time, it is necessary to launch active employment and vocational training policies for workers in order to encourage flexicurity as a strategy, achieving a good balance between flexibility of labor markets and employment organizations on the one hand, and employment and social security, on the other hand (Wilthagen and Tros, 2004).

Since our objective was to investigate the role of resources on WFE, we adopted the JD-R model (Bakker and Demerouti, 2007), that appears particularly interesting due to its flexibility as it permits to consider various types of job resources and their effects on different outcomes. Therefore, such approach allowed us to fill a gap in the literature where few resources have been considered in relation to WFE (Bakker et al., 2011). 
The JD-R model was originally designed to explain which combination of job demands and job resources influences well-being (e.g. burnout and work engagement). Nevertheless, it can also be suitable to explain the complex relationship between work and family life (Demerouti, Bakker and Bulters, 2004), "beyond the organizational border" (Bakker et al., 2011), because the work and family domains have become inextricably bound to each other (Voydanoff, 2005).

The present study focuses only on the role of job resources; in fact, they are important not only as they may compensate for the impact of job demands, but also because they have a positive role per se (Bakker and Demerouti, 2007). Specifically, the JD-R model implies a process in which job resources play both an intrinsic motivational role - they foster employees' growth, learning and development - and an extrinsic motivational role - they are instrumental in achieving work goals (Bakker and Demerouti, 2007).

Considering that studies of the work-family interface based on the JD-R model have focused mainly on the buffering effects of job resources on the relationship between job demands and outcomes (Bakker et al., 2011), this study aims to improve the knowledge about the other process involved in the model, investigating the direct effects of job resources on WFE. Specifically, consistent with the literature, we expect a direct effect of job resources on WFE (Carlson et al., 2006; Odle-Dusseau et al., 2012; Siu et al., 2010).

Hypothesis 2 (H2): job resources (colleague support, supervisor support and job security) increase WFE.

Moreover, as regards professional development, if it is a resource per se, it can also be influenced by other job resources which improve workplace learning practices, supporting the ability of workers to cope more effectively with negative events and threatening circumstances. 
Hypothesis 3 (H3): job resources (colleague support, supervisor support and job security) increase OPD.

Finally, considering the role that job resources play in the processes involved in the JD-R model, and considering their potential direct effect on WFE (Carlson et al., 2006), we expect that also OPD increases WFE and, consequently, partially mediates the relationship between the other job resources and WFE.

Hypothesis 4 (H4): the effect of job resources on WFE is partially mediated by OPD.

Figure 1 shows the theoretical model representing the 4 study hypotheses.

----- FIGURE 1 -----

\section{Method}

\section{Participants}

The research involved a convenience sample of 353 employees and self-employed workers (working continuously as consultants in small-middle size organizations) from different occupational sectors: $40 \%$ were from public and private service sectors, $12 \%$ were from education and research, $37 \%$ were from industry and commerce and 5\% were from public health (missing cases $=6 \%$ ). The sample has been collected via a snowball exercise; respondents received an e-mail explaining the purpose of the research and were asked to fill in an online self-report questionnaire. The sample consisted of $52 \%$ females and $48 \%$ males, aged between 19 and $61(M=36.33 ; S D=$ 9.92) and $33 \%$ having children. In the sample, $55 \%$ had a bachelor's or master's degree, the remaining $45 \%$ had a lower educational qualification. Most of the participants (63\%) had permanent 
employment contracts, $18 \%$ had fixed-term ones and $13 \%$ were self-employed (missing cases $=$ $6 \%)$. Weekly working hours were, on average, $41.27(S D=9.31 ; \min =8 ; \max =70)$.

\section{Measures}

Supervisor support was measured by 4 items (Karasek et al., 1998) with a 4-point Likert scale from $1=$ strongly disagree to $4=$ strongly agree ("My supervisor is concerned about the welfare of those under him").

Colleague support was measured by 4 items (Karasek et al., 1998) with a 4-point Likert scale from $1=$ strongly disagree to 4 = strongly agree ("People I work with take a personal interest in me").

Job security was measured by 3 items (Kraimer et al., 2005) with a 7-point Likert scale from $1=$ totally disagree to $7=$ totally agree ("My job will be there as long as I want it").

$O P D$ were measured by 4 items (Bakker et al., 2003) with a 5-point Likert scale from $1=$ totally disagree to $5=$ totally agree ("My work offers me the opportunity to learn").

WFE was measured by 3 items (Ghislieri et al., 2011) with a 5-point Likert scale from $1=$ strongly disagree to $5=$ strongly agree ("At work I feel positive emotions and this helps me to be a better family member").

\section{Data analysis}

The statistical package PASW 18 was used for descriptive analysis (means and standard deviation), internal consistency of each scale and to analyze the correlations among variables through Pearson's coefficient. We controlled for gender, age, mean seniority on the job and having children in all analyses. The empirical model of the relationship between variables was investigated by structural equation modeling (SEM) which estimates a complete model, incorporating both measurement and structural considerations (Bollen, 1989). SEM analysis was assessed by the software Mplus 6 (Muthén and Muthén, 1998-2007). Moreover, the Sobel test (Baron and Kenny, 1986; Sobel, 1982) has been applied to verify the significance of mediational effects. To address the 
common method variance issue we performed a confirmatory factor analysis using the Harman's single-factor test (Podsakoff et al., 2003). Results indicated that one single factor could not account for the variance in the data $\left[\chi^{2}(135)=1748.15, p<.01, \mathrm{RMSEA}=.18, \mathrm{CFI}=.50, \mathrm{TLI}=.44\right.$, $\operatorname{SRMR}=.14$.$] and therefore the threat of common method bias is unlikely.$

\section{Results}

Table 1 shows descriptive statistics, reliability and correlations among all variables. All scales presented acceptable reliabilities, since Cronbach's alphas ranged from .77 to .89 . Analysis showed a high positive correlation between WFE and OPD. Moreover, both WFE and OPD correlated with all job resources considered (supervisor support, colleague support, job security).

\section{----- TABLE 1 -----}

\section{TABLE 2 -----}

Table 2 displays the results of three SEM models, comparing the "no mediation", the "full mediation" and the "partial mediation" role of OPD. Model 3 (partial mediation) had a statistically significant better fit than both Model 1 (no mediation), $\Delta \chi^{2}{ }_{\mathrm{M} 1-\mathrm{M} 3}(6)=225.16, p<.01$ and Model 2 (full mediation), $\Delta \chi^{2}{ }_{\mathrm{M} 2-\mathrm{M} 3}(3)=13.05, p<.01$. Thus, we adopted Model 3, which is graphically represented in Figure 2; all items had significant factor loadings, between .57 and .95. OPD mediated the relationship between the two job resources taken into account on the one hand, supervisor support (Sobel test, $t=4.03, p<.001$ ) and job security (Sobel test, $t=5.79, p<.001$ ), and WFE on the other. Colleague support had a weaker significant direct effect on WFE, although it is demonstrated that variation in WFE was explained above all by OPD.

The model also showed a correlation between two items on the colleague support scale, $\mathrm{CS}_{2}$ and $\mathrm{CS}_{3}$, which seem to be the items that investigate the personal, more than the professional, closeness 
and interest among colleagues. Moreover, there is a correlation between items $\mathrm{WFE}_{1}$ and $\mathrm{WFE}_{2}$ from the WFE scale. They appear to be mainly focused on characteristics of work (e.g., professional skills and positive emotions) that generate an explicit enrichment from work to family, more than other aspects such as sense of accomplishment.

\section{----- FIGURE 2 -----}

\section{Discussion and conclusion}

The main aim of this study was to investigate the role of OPD as a mediator between other job resources (colleague support, supervisor support and job security) and WFE, according to the JD-R model. The mediation model showed a good fit to the data and was consistent with the theoretical model of the study.

As regards to the first hypothesis, results showed that OPD strongly increase WFE. It can be concluded that opportunities to learn at work, to grow professionally, to see one's strengths enhanced, may not only prevent negative outcomes (Salanova, Agut and Peiro, 2005) and foster decent work environments (Lee, 1998), but may also assume a decisive role in promoting the enrichment from work to family (Bakker and Geurts, 2004). Further research, including qualitative and longitudinal studies, should investigate whether the process activated by OPD is both instrumental and affective. In fact, OPD allow for both the acquisition of skills which can be used directly in the family domain, and an overall improvement of self-image through the enhancement of personal strengths.

Concerning the second hypothesis, only colleague support showed a direct effect, albeit weak, on WFE, in line with the literature that suggests the importance of some organizational interests and support in promoting WFE (Carlson et al., 2006). More specifically, enrichment is directly related to the quality of relationships with colleagues, as the latter is a resource capable of fostering an 
environment more conducive to having positive experiences at work, which can be expressed in forms of enrichment outside work.

Regarding the third hypothesis, results confirmed the ones of recent studies on workplace development processes (Rafferty and Griffin, 2004) and showed that supervisor support has a direct effect on OPD. This finding is particularly interesting, as it highlights that in the presence of supportive leaders more OPD emerge, or, if nothing else, they are perceived more strongly by workers. A different interpretation is also possible, one to be examined more closely in future research: the relationship with supervisors, and the opportunity of reciprocal feedback, might be a resource and an opportunity for professional development in se and per se (Cortese, 2007).

Concerning colleague support, results did not show a positive impact on OPD. It is possible that, in Italian organizations characterized by hierarchical relationships, workers are unable, or not allowed, to contribute to their colleagues' professional development and learning. In the future, qualitative research should investigate these aspects, with particular attention to the specificity of the Italian working contexts.

Finally, job security significantly increased OPD, which is the finding that could be considered the most original contribution of this study. Feeling a sense of security towards one's job is an important resource to enhance the perception of professional growth, and the sense of continuity over time. On the one hand, employees with permanent contracts, in big and well-established companies, receive more important and continuous investments in their professional development. On the other hand, however, job security might be considered by the workers as a "guarantee", confirming that the company is investing in them for the long run. It would be interesting, in future research, to also investigate the role of the psychological contract in understanding the effect of job security on professional development.

Since there are no other studies on the relationship between job security and OPD, the findings of this research may be considered distinctive of the Italian cultural context, where the issue of job security may be particularly relevant, especially in times of crisis. It would be interesting to study 
this hypothesis more thoroughly through cross-national studies (Kohn, 1989; Sousa-Poza and Sousa-Posa, 2000).

In general, these results appear to be in line with the conclusions of several authors (Bakker and Demerouti, 2007; Van Ruysseveldt, Verboon and Smulders, 2011), identifying that the lack of resources precludes concrete goal accomplishment and undermines employee learning opportunities.

Finally, concerning the last study hypothesis, the empirical model showed that the effect of two resources, supervisor support and job security, on WFE is mediated by OPD. Therefore, this study highlighted the significant mediational role of OPD, suggesting that OPD are an important factor that enables WFE and should be integrated into theoretical work-family studies and practical implications.

\section{Research limitations}

Although these results are interesting by themselves, the study presents several limitations. With regards to the research design, as already mentioned in part, longitudinal research would be necessary to evaluate causal links. Moreover, it would be of great utility to go beyond mere selfappraisal of the variables under examination, by considering some "objective" data (e.g., type of job contract) and for the dependent variables appraisal by others (in the case of enrichment, for example, by the partner).

As for those variables included in the study, OPD should be operationalized more precisely, examining its sub-dimensions more carefully (Rau, 2006), and giving attention also to formal training or career development practices.

In addition, this study did not consider certain important job resources, including, for instance, autonomy and variety of tasks which might have significant relationships with both OPD and WFE. Professional development, indeed, is expected in jobs with high degrees of freedom in procedure and time management, requirements of skill enhancement, decision making, and responsibility 
(Dunckel, 2002). Moreover, several studies have pointed to the importance of task variety in workplace learning (Van Ruysseveldt, Verboon and Smulders, 2011; Wielenga-Meijer et al., 2010). Support outside the workplace, mainly family support, might be also considered (Peeters and Le Blanc, 2001), as well as the WFC dimension to take a dual conflict and enhancement perspective on the work-family interface.

This study, like other research on enrichment (Siu et al., 2010), focuses exclusively on the effect of resources. However, some demands might have a role in enrichment dynamics. Wayne, Randel and Stevens (2006) highlighted, for example, that organizational time demands negatively predicted WFE. Consistent with the JD-R model and its hypotheses, it would be very valuable to focus future studies on the role of job demands, and on the relationship between them and job resources.

In addition, some authors (Van Ruysseveldt et al., 2011; Xanthopoulou et al., 2009) have assumed that learning opportunities might play a health-promoting role through the promotion of personal resources. From this perspective, future research should focus on the relationship between OPD and the development of personal resources (such as self-efficacy, optimism, self-esteem or feelings of mastery).

Lastly, the study does not allow for observation of differences based on occupation or organization: which also indicates a possible development or approach for the future.

\section{Practical implications}

Despite these limitations, the study is significant at a practical level. Job security, in particular, is highly relevant today, when this issue is being debated in Italy also at a political level. It is therefore important to include this element in studies linked to those work dynamics which may affect quality of life both at work and outside. Our research shows how job security can increase OPD, which in turn have a positive influence on WFE: this result suggests that, in Italy, at least, greater protection in terms of job security could have beneficial effects on the quality of life. 
As concerns the role of supervisors, the results of the research highlight the importance of the selection of leaders and of the training for leadership, at different levels of the organization. This element is indeed strongly linked to OPD. Such training would, on the one hand, promote transformational leadership (Avolio and Bass, 1999; Bass, 1998; Yee et al., 2011), and on the other hand, more practically, enable direct superiors to be more diligent in providing their co-workers with more opportunities to gain experience, to learn on the job and to receive training in the classroom.

The relationship between OPD, WFE and training is certainly a topic which requires further examination: training, whether it be in the classroom, on the job or by distance learning, may therefore represent an important tool to make the individuals feel they are experiencing continual growth, on a learning path which goes hand in hand with daily work life, as a form both of enhancing personal resources and of recognition of personal potential.

In conclusion, highlighting two of the most important lessons learnt from this research, organizations should give both employees with a permanent or fixed-term contract the same OPD (Torka and Schyns, 2007); in this way, also workers in situations of low job security will perceive investments in their professional development from organizations, and consequently improve their WFE. Secondly, organizations should not consider the investments intended to OPD for workers and to leadership training for supervisors in competition with those for initiatives of organizational welfare, because all these interventions contribute to a positive integration between work and family domains.

\section{References}

Avolio, B.J. and Bass, B.M. (1999), "Re-examining the component of transformational and transactional leadership using the multifactor leadership questionnaire", Journal of Occupational and Organizational Psychology, Vol. 72 No. 4, pp. 441-62. 
Bakker, A.B. and Demerouti, E. (2007), "The Job Demands-Resources model: State of the art", Journal of Managerial Psychology, Vol. 22, 309-28.

Bakker, A.B. and Geurts, S.A.E. (2004), “Toward a Dual-Process Model of Work-Home Interference", Work and Occupations, Vol. 31, 345-66.

Bakker, A.B., Brummelhuis, L.L.T., Prins, J.T. and van der Heijen, F.M.M.A. (2011), “Applying the job demands-resources model to the work-home interface: A study among medical residents and their partners", Journal of Vocational Behavior, Vol. 79, 170-80.

Bakker, A.B., Demerouti, E., Taris, T.W., Schaufeli, W.B. and Schreurs, P.J.G. (2003), “A multigroup analysis of the job demands-resources model in four home care organizations", International Journal of Stress Management, Vol. 10, 16-38.

Barnett, R.C. (1998), "Toward a review and reconceptualization of the work-family interface", Genetic, Social, and General Psychology Monographs, Vol. 124, 125-82.

Barnett, R.C. and Hyde, J.S. (2001), "Women, men, work, and family", American Psychologist, Vol. 56, 781-96.

Baron, R.M. and Kenny, D.A. (1986), "Moderator - Mediator Variables Distinction in Social Psychological Research: Conceptual, Strategic, and Statistical Considerations”, Journal of Personality and Social Psychology, Vol. 51 No. 6, 1173-82.

Bass, B. (1998), Transformational Leadership: Industrial, Military, and Educational Impact, Lawrence Erlbaum Associates, Inc, Mahwah, NJ.

Bollen, K.A. (1989), Structural equations with latent variables, Wiley, New York.

Briscoe, J.P., Hall, D.T. and De Muth, R.L.F. (2006), "Protean and boundaryless careers: An empirical exploration”, Journal of Vocational Behavior, Vol. 69, No. 1, 4-18.

Carlson, D., Kacmar, K.M., Zivunska, S. and Ferguson, M. (2011), "Work-family enrichment and job performance: A constructive replication of affective events theory", Journal of Occupational Health Psychology, Vol. 16, No. 3, 297-312. 
Carlson, D.S., Kacmar, K.M., Wayne, J.H. and Grzywacz, J.G. (2006), "Measuring the positive side of the work-family interface: Development and validation of a work-family enrichment scale", Journal of Vocational Behavior, Vol. 68, 131-64.

Cobb, S. (1976), "Social support as moderator of life stress", Psychosomatic Medicine, Vol. 38, $300-14$.

Coetzer, A. (2007), "Employee perceptions of their workplaces as learning environments", Journal of Workplace Learning, Vol. 19, 417-34.

Connelly, C.E. and Gallagher, D.G. (2004), "Emerging trends in contingent work research", Journal of Management, Vol. 30, 959-83.

Cortese, C.G. (2007), "Job satisfaction of Italian nurses: An exploratory study”, Journal of Nursing Management, Vol. 15, No. 3, 303-12.

Cox, T., Griffiths, A. and Rial-Gonzales, E. (2000), Work-related Stress, Office for Official Publications of the European Communities, Luxembourg.

Crouter, A.C. (1984), "Spillover from family to work: The neglected side of the work-family interface", Human Relations, Vol. 37, 425-42.

Demerouti, E., Bakker, A.B. and Bulters, A.J. (2004), “The loss spiral of work pressure, work-home interference and exhaustion: Reciprocal relations in a three-wave study", Journal of Vocational Behavior, Vol. 64, 131-49.

Demerouti, E., Bakker, A.B. and Voydanoff, P. (2010), "Does home life interfere with or facilitate job performance", European Journal of Work and Organizational Psychology, Vol. 19, $128-49$.

Demerouti, E., Geurts, S.A.E and Kompier, M.A.J. (2004), "Positive and negative work-home interaction: Prevalence and correlates”, Equal Opportunities International, Vol. 23, 6-35.

Ducharme, L.J. and Martin, J.K. (2000), "Unrewarding work, coworker support, and job satisfaction", Work and Occupations, Vol. 27, 223-43. 
Dunckel, H. (2002), "Job analysis and work roles", in Smelser, N.J. and Baltes, P.B. (Eds.), International encyclopedia of the social and behavioral sciences (pp. 7973-7), Elsevier, London.

Edwards, J.R. and Rothbard, N.P. (2000), "Mechanism linking work and family: Clarifying the relationship between work and family constructs", Academy of Management Review, Vol. $25,178-99$.

Elman. N.S., Illfelder-Kaye, J. and Robiner, W.N. (2005), "Professional Development: Training for Professionalism as a Foundation for Competent Practice in Psychology", Professional Psychology: Research and Practice, Vol. 36, 367-75.

Falco, A., Dal Corso, L., De Carlo, A. and Di Sipio, A. (2008), "Effects of temporary job contracts on the well-being of individuals and organizations", TPM - Testing, Psychometrics, Methodology in Applied Psychology, Vol. 15, No. 4, 193-209.

Frone, M.R., Russell, M. and Cooper, M.L. (1992), “Antecedents and outcomes of work-family conflict: testing a model of the work-family interface", Journal of Applied Psychology, Vol. 77, 65-78.

Gareis, K.C., Barnett, R.C., Ertel, K.A. and Berkman, L.F. (2009), "Work-family enrichment and conflict: Additive effects, buffering, or balance?", Journal of Marriage and Family, Vol. $71,696-707$.

Ghislieri, C., Martini, M., Gatti, P. and Colombo, L. (2011), "The "bright side” of the work-family interface: A brief work-family enrichment scale in a sample of health professionals", TPM - Testing, Psychometrics, Methodology in Applied Psychology, Vol. 18, No. 4, 211-30.

Goode, W.J. (1960), “A theory of role strain”, American Sociological Review, Vol. 25, 483-96.

Greenhaus, J.H. and Beutell, N. (1985), "Sources of conflict between work and family roles", Academy of Management Review, Vol. 10, 76-88.

Greenhaus, J.H. and Powell, G.N. (2006), "When work and family are allies: A theory of workfamily enrichment", Academy of Management Review, Vol. 31, 72-92. 
Grzywacz, J.G. (2002), Toward a theory of work-family enrichment, Paper presentation, 34th Annual Theory Construction and Research Methodology Workshop, Houston, TX.

Hammer, L.B. and Hanson, G. (2006), "Work-family enrichment", in Greenhaus, G.H. and Callanan, C.A. (Eds.), Encyclopedia of career development, Thousand Oaks, CA, Sage.

Hanson, G.C., Hammer, L.B. and Colton, C.L. (2006), "Development and validation of a multidimensional scale of perceived work-family positive spillover", Journal of Occupational Health Psychology, Vol. 11, 249-65.

Hill, E.J., Allen, S., Jacob, J., Bair, A.F., Bikhazi, S.L., Van Langeveld, A.V., Martinengo, G., Trost Parker, T. and Walker, E. (2007), "Work-family facilitation: Expanding theoretical understanding through qualitative exploration", Advances in Developing Human Resources, Vol. 9, 507-26.

Holman, D. and Wall, T. (2002), "Work characteristics, learning-related outcomes, and strain: A test of competing direct effects, mediated, and moderated models", Journal of Occupational Health Psychology, Vol. 7, 283-301.

Jacobs, R.L. and Park, Y. (2009), “A Proposed Conceptual Framework of Workplace Learning: Implications for Theory Development and Research in Human Resource Development”, Human Resource Development Review, Vol. 8, 133-50.

Karasek, R., Brisson, C., Kawakami, N., Houtman, I., Bongers, P. and Amick, B. (1998), “The Job Content Questionnaire (JCQ): An instrument for internationally comparative assessments of psychosocial job characteristics”, Journal of Occupational Health Psychology, Vol, 3, $322-55$

Kirchmeyer, C. (1993), "Nonwork-to-work spillover: A more balanced view of the experiences and coping of professional women and men”, Sex Roles, Vol. 28, 531-52.

Kohn, M.L. (1989), Cross-National Research as an Analytic Strategy, Sage Publications, Newbury Park. 
Kompier, A.J. (2006), “New systems of work organization and workers' health", Scandinavian Journal of Work, Environment \& Health, Vol. 32, 421-30.

Kraimer, M.L., Wayne, S.J., Liden, R.C. and Sparrowe, R.T. (2005), “The Role of Job Security in Understanding the Relationship Between Employees' Perceptions of Temporary Workers and Employees' Performance”, Journal of Applied Psychology, Vol. 90, 389-98.

Lapierre, L.M. and Allen, T.D. (2006), "Work-supportive family, family-supportive supervision, use of organizational benefits, and problem-focused coping: Implications for work-family conflict and employee well-being", Journal of Occupational Health Psychology, Vol. 11, $169-81$.

Lee, T. (1998), “Assessment of safety culture at a nuclear reprocessing plant”, Work and Stress, Vol. 12, 217-37.

MacDermid, S.M. (2005), "(Re)considering conflict between work and family", in Kossek E.E. amd Lambert, S.J. (Eds.), Work and life integration (pp. 19-40), Lawrence Erlbaum Associates, London.

Major, D.A. and Germano, L.M. (2006), “The changing nature of work and its impact on the workhome interface", in Jones, F., Burke, R.J. and Westman, M. (Eds.), Work-life balance. A psychological perspective (pp. 13-38), Psychology Press, Hove, East Sussex.

Marks, S.R. (1977), "Multiples roles and role strain: Some notes on human energy, time and commitment”, American Sociological Review, Vol. 42, 921-36.

Michel, J.S. and Clark, A.M. (2009), “Has it been affected all along?”, Personality and Individual Differences, Vol. 47, 163-8.

Morrison, D., Cordery, J., Girardi, A. and Payne, R. (2005), “Job design, opportunities for skill utilization, and intrinsic job satisfaction”, European Journal of Work and Organizational Psychology, Vol. 14, 59-79.

Muthén L.K. and Muthén B.O. (1998-2007), Mplus user’s guide, Muthén \& Muthén, Los Angeles. 
O’Driscoll, M., Brough, P. and Kalliath, T. (2006), "Work-family conflict and facilitation”, in Jones, F., Burke, R.J. and Westman, M. (Eds.), Work-life balance. A psychological perspective (pp. 117-42), Psychology Press, Hove, East Sussex.

Odle-Dusseau, H., Britt, T.W. and Greene-Shortridge, T.M. (2012), “Organizational work-family resources as predictors of job performance and attitudes: The process of work-family conflict and enrichment”, Journal of Occupational Health Psychology, Vol. 17, No. 1, 28 40.

Ouweneel, A.P.E., Taris, T.W., van Zolingen, S.J. and Schreurs, P.J.G. (2009), “How Task Characteristics and Social Support Relate to Managerial Learning: Empirical Evidence From Dutch Home Care", The Journal of Psychology, Vol. 143, 28-44.

Panari, C., Guglielmi, D., Simbula, S. and Depolo, M. (2010), "Can an opportunity to learn at work reduce stress? A revisitation of the job demand-control model", Journal of Workplace Learning, Vol. 22, 166-79.

Peeters, M.C.W. and Le Blanc, P.M. (2001), “Towards a match between job demands and sources of social support: A study among oncology care providers", European Journal of Work and Organizational Psychology, Vol. 10, 53-72.

Podsakoff, P.M., MacKenzie, S.B., Lee, J.L. and Podsakoff, N.P. (2003), “Common method biases in behavioral research: A critical view of the literature and recommended remedies", Journal of Applied Psychology, Vol. 88, 879-903. doi:10.1037/0021-9010.88.5.879.

Poelmans, S., O’Driscoll, M. and Beham, B. (2005), “An overview of international research on the work-family interface", in Poelmans, S.S.Y. (Ed.), Work and Family. An international research perspective (pp. 3-46), Lawrence Erlbaum, Mahwah, New Jersey.

Pombeni M.L. and Vattovani P., (2005), Centri dedicati per un sistema integrato di orientamento. Differenze per qualificare, Franco Angeli, Milano.

Rafferty, A.E. and Griffin, M.A. (2004), “Dimensions of transformational leadership: Conceptual and empirical extensions", The Leadership Quarterly, Vol. 15, 329-54. 
Rau, R. (2006), “Learning opportunities at work as predictor for recovery and health”, European Journal of Work and Organizational Psychology, Vol. 15, 158-80.

Rothbard, N.P. and Dumas, T.L. (2006), "Research perspectives: managing the work-home interface", in Jones, F., Burke R.J. and Westman, M. (Eds.), Work-life balance. A psychological perspective (pp. 71-89). Psychology Press, Hove, East Sussex.

Salanova, M., Agut, S. and Peiro, J.M. (2005), "Linking organizational resources and work engagement to employee performance and customer loyalty: the mediation of service climate", Journal of Applied Psychology, Vol. 90, 1217-27.

Shockley, K.M. and Singla, N. (2011), "Reconsidering work-family interactions and satisfaction: A meta-analysis", Journal of Management, Vol. 37, No. 3, 861-86.

Sieber, S.D. (1974), “Toward a theory of role accumulation”, American Sociological Review, Vol. $34,567-78$.

Siu, O., Lu, J, Brough, P., Lu, C., Bakker, A.B., Kalliath, T., O’Driscoll, M., Phillips, D.R., Chen, W., Lo, D., Sit, C. and Shi, K. (2010) "Role resources and work-family enrichment: The role of work-engagement", Journal of Vocational Behavior, Vol. 77, 470-80.

Sobel, M.E. (1982), “Asymptotic intervals for indirect effects in structural equations models”, in Leinhart, S. (Ed.), Sociological methodology 1982 (pp. 290-312), Jossey-Bass, San Francisco.

Sousa-Poza, A. and Sousa-Posa, A.A. (2000), "Well-being at work: A cross-national analysis of the levels and determinants of job satisfaction", The Journal of Socio-Economics, Vol. 29, $517-38$

Sugarman, B. (2001), “A learning-based approach to organizational change: some results and guidelines", Organizational Dynamics, Vol. 30, No. 1, 62-76.

Theorell, T. and Hasselhorn, H.M. (2005), “On cross-sectional questionnaire studies of relationship between psychosocial condition at work and health-are they reliable", International Archives of Occupational and Environmental Health, Vol. 78, 517-22. 
Thoits, P.A. (1983), "Multiple identities and psychological well-being: A reformulation of the social isolation hypothesis", American Sociological Review, Vol. 48, 174-87.

Tiedje, L.B., Wortman, C.B., Downey, G., Emmons, C., Biernat, M. and Lang, E. (1990), “Women with multiple roles: Role-compatibility perceptions, satisfaction, and mental health", Journal of Marriage and the Family, Vol. 52, 63-72.

Torka, N. and Schyns, B. (2007), "On the transferability of 'traditional' satisfaction theory to nontraditional employment relationships: temp agency work satisfaction", Employee Relations, Vol. 29, No. 5, 440-57.

Tracey, J.B., Tannenbaum, S.I. and Kavanaugh, M.J. (1995), “Applying trained skills on the job: The importance of the work environment”, Journal of Applied Psychology, Vol. 80, 23952.

Van Ruysseveldt, J., Verboon, P. and Smulders, P. (2011), "Job resources and emotional exhaustion: The mediating role of learning opportunities", Work \& Stress, Vol. 25, 20523.

Voydanoff, P. (2005), “Toward a conceptualization of perceived work-family fit and balance: A demands and resources approach", Journal of Marriage and Family, Vol. 67, No. 4, 82236.

Wayne, J., Musisca, N. and Fleeson, W. (2004), "Considering the role of personality in the workfamily experience: relationship of the big five to work-family conflict and facilitation", Journal of Vocational Behavior, Vol. 64, 108-30.

Wayne, J.H., Randel, A.E. and Stevens, J. (2006), “The role of identity and work-family support in work-family enrichment and its work-related consequences", Journal of Vocational Behavior, Vol. 69, 445-61.

Wielenga-Meijer, E., Taris, T., Kompier, M. and Wigboldus, D. (2010), "From task characteristics to learning: A systematic review", Scandinavian Journal of Psychology, Vol. 51, 363-75. 
Wilthagen, T. and Tros, F. (2004), “The concept of 'flexicurity': a new approach to regulating employment and labour markets", Transfer: European Review of Labour and Research Summer, Vol. 10, 166-86.

Xanthopoulou, D., Bakker, A.B., Demerouti, E. and Schaufeli, W.B. (2009), "Reciprocal relationships between job resources, personal resources, and work engagement”, Journal of Vocational Behavior, Vol. 74, 235-44.

Yanchus, N.J., Eby, L.T., Lance, C.E. and Drollinger, S. (2010), “The impact of emotional labor on work-family outcomes”, Journal of Vocational Behavior, Vol. 76, 105-17.

Yee, R.W.Y., Lee, P.K.C., Yeung, A.C.L. and Cheng, T.C.E. (2011), “The relationship among leadership, goal orientation, and service quality in high-contact service industries: An empirical study", International Journal of Production Economics, doi: 10.1016/j.ijpe.2011.12.012. 
Table 1. Descriptive statistics, reliabilities and correlations among all variables.

\begin{tabular}{lcccccccc}
\hline & M & SD & $\boldsymbol{\alpha}$ & $\mathbf{1}$ & $\mathbf{2}$ & $\mathbf{3}$ & $\mathbf{4}$ & $\mathbf{5}$ \\
\hline 1. WFE & 2.71 & 1.09 & .88 & 1 & & & & \\
\hline 2. OPD & 3.29 & .97 & .86 & $.58^{* *}$ & 1 & & & \\
\hline 3. Supervisor support & 2.56 & .82 & .87 & $.44^{* *}$ & $.43^{* *}$ & 1 & & \\
\hline 4. Colleague support & 2.84 & .64 & .77 & $.37^{* *}$ & $.28^{* *}$ & $.52^{* *}$ & 1 & .10 \\
\hline 5. Job security & 4.07 & 1.69 & .89 & $.21^{* *}$ & $.35^{* *}$ & $.14^{*}$ & .1 \\
\hline$* * p<.01, * p<.05$. & & & & & & &
\end{tabular}

Table 2. Results of mediated SEM analysis.

\begin{tabular}{lccccccc}
\hline & $\boldsymbol{\chi}^{\mathbf{2}}$ & $\boldsymbol{d} \boldsymbol{f}$ & $\boldsymbol{p}$ & $\boldsymbol{C F I}$ & TLI & RMSEA (90\% CI) & SRMR \\
\hline M1. No mediation & 457.86 & 129 & $<.01$ & .90 & .89 & $.09(.08,1.00)$ & .18 \\
\hline M2. Full mediation & 245.75 & 126 & $<.01$ & .97 & .96 & $.05(.04, .06)$ & .05 \\
\hline M3. Partial mediation & 232.70 & 123 & $<.01$ & .97 & .96 & $.05(.04, .06)$ & .04 \\
\hline
\end{tabular}


Figure 1. Theoretical model.

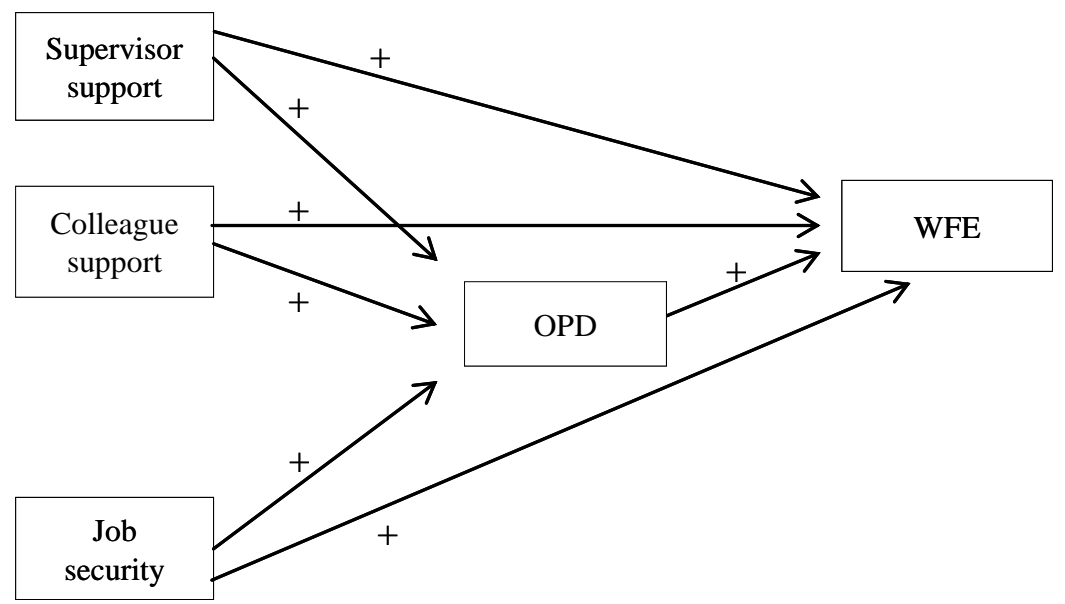

Figure 2. The empirical structural equation modeling (standardized solution).

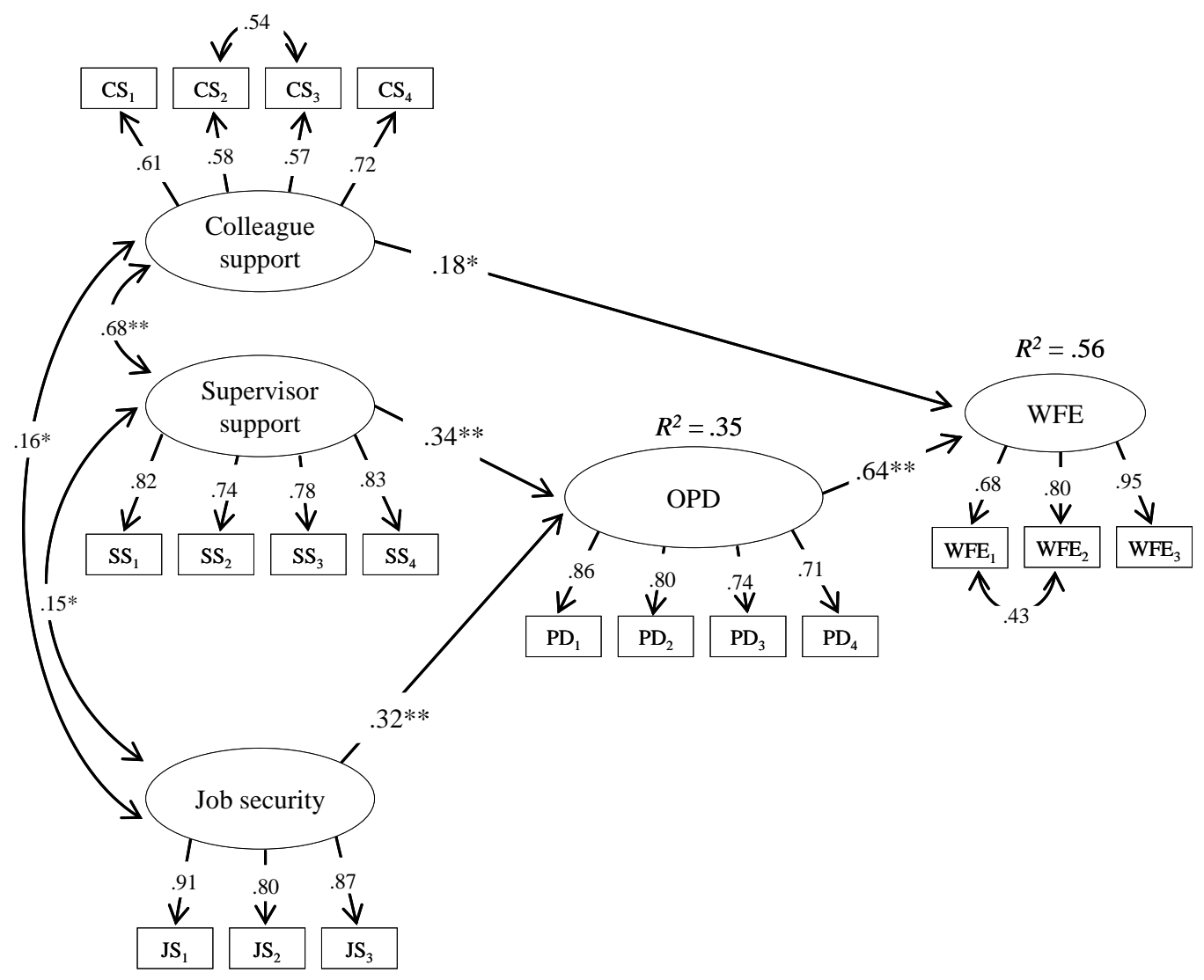

${ }^{* *} p<.001, * p<.05$. 